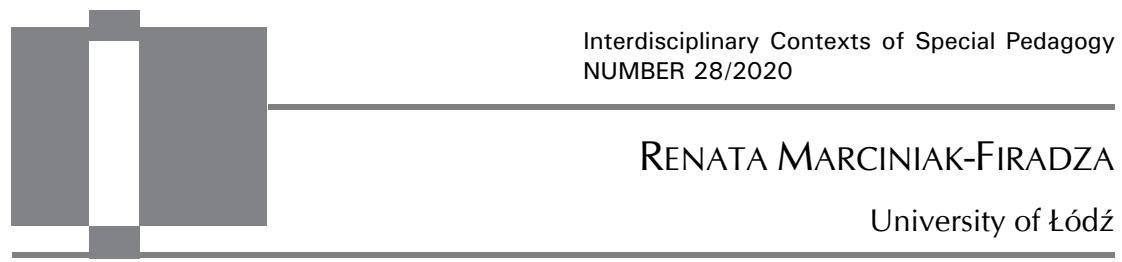

\title{
Types of grammatical and lexical errors made by students with a mild intellectual disability at the second stage of their education a qualitative analysis
}

\begin{abstract}
Renata Marciniak-Firadza, Types of grammatical and lexical errors made by students with a mild intellectual disability at the second stage of their education a qualitative analysis. Interdisciplinary Contexts of Special Pedagogy, no. 28, Poznań 2020. Pp. 149-170. Adam Mickiewicz University Press. ISSN 2300-391X. e-ISSN 2658-283X. DOI: https://doi.org/10.14746/ikps.2020.28.08

The aim of the article is to provide a qualitative description of the errors committed by pupils with mild intellectual disabilities. The discussed issue has not yet been the subject of a scientific description from a linguistic point of view. The analysis of errors was based on Andrzej Markowski's classification with small additions from Zygmunt Saloni's classification. Due to the volumetric framework, the article is limited to discussing grammatical and lexical errors.

The research showed that pupils with mild intellectual disabilities make similar errors as those with typical development. No qualitative differences were noted between the study group and the control group, only quantitative ones.
\end{abstract}

KEY WORDS: grammatical errors, lexical errors, intellectual disabilities 


\section{Introduction}

Language proficiency in humans is defined by linguists (especially those from the generative linguistics school created by Noam Chomsky) using the term of the language competence. ${ }^{1}$ On the one hand, Noam Chomsky defines language competence as the ideal knowledge and ability of a given language user to understand sentences in terms of their grammar and semantics, and on the other hand, the ability to create new sentences. ${ }^{2}$ In the literature the terms of language skills, language awareness are also found. ${ }^{3}$

Language competence is essential for a human being in the process of communication, and the nature of every human being includes a need to create and transfer meanings. The discussed competence is also necessary for a person with intellectual disability and usually such a person finds in the individual repertoire of knowledge and skills, linguistic measures to express their intentions. ${ }^{4}$ Although we generally understand and know what a person with intellectual disability wants to communicate to us (especially in the case of a mild intellectual disability), we are aware that in the statements of such a person linguistic errors appear, especially since in this case language knowledge remains in relation to the vague knowledge of the world. It is not difficult to make mistakes - as A. Wątorek writes - if language competence consists of both information gathered as a result

${ }^{1}$ I. Kurcz, "Kompetencja językowa i kompetencja komunikacyjna: ich uwarunkowania biologiczne i społeczne. Model wiedzy językowej człowieka", [in:] Jezzyk jako przedmiot badań psychologicznych. Psycholingwistyka ogólna i neurolingwistyka, Kurcz I., Okuniewska H. (eds.), Wydawnictwo SWPS, Warsaw, 2011, p. 35.

2 After: M. Mnich, Sprawność jezzykowa dzieci w wielu wczesnoszkolnym, Impuls, Cracow, 2002.

${ }^{3}$ In the studies of child's speech language skills are most often related to the ability to use the language properly at a particular stage of speech development, as well as the knowledge of specific elements of the linguistic system and linguistic norm by a child of a certain age (after: M. Mnich, Sprawność językowa dzieci w wielu wczesnoszkolnym, Impuls, Cracow, 2002).

${ }^{4} \mathrm{Cf}$. A. Wątorek, Kompetencja językowa uczniów z lekką niepetnosprawnością intelektualna, Wydawnictwo Nomos, Cracow, 2014, p. 87. 
of inaccurate processing of sound and image material, as well as not fully controlled activities of planning own statements. ${ }^{5}$

To achieve a certain level of language competence, it is necessary pass through a period of its gaining in two, according to Canadian psychologist Stephen Krashen, main processes of acquisition and learning. Both these processes interpenetrate. ${ }^{6}$ English sociologist Basil Bernstein, ${ }^{7}$ searching for the relationship between different language use norms and the effects of school education, noted that the language competence of the student depends on the speech system acquired in the family, as early as before starting school education. On the other hand, in the didactic process, the language of a student is subjected to particular educational activities by the improvement of specific language and stylistic skills,${ }^{8}$ and the education process is to lead to a conscious mastery of spoken and written language rules. ${ }^{9}$ It should be emphasised that, apart from social and didactic conditions, success in language learning by a child depends largely on a number of innate predispositions: hearing, memory, imitation abilities, analysis and synthesis skills, etc.

Although in the case of the topic of language competence of students characterised by a so-called typical development, fairly extensive source literature is available, ${ }^{10}$ in the case of students with

${ }^{5}$ A. Wątorek, Kompetencja językowa uczniów z lekkq niepetnosprawnością intelektualna, Wydawnictwo Nomos, Cracow, 2014, p. 86.

${ }^{6}$ I. Kurcz, "Kompetencja językowa i kompetencja komunikacyjna: ich uwarunkowania biologiczne i społeczne. Model wiedzy językowej człowieka", [in:] Język jako przedmiot badań psychologicznych. Psycholingwistyka ogólna i neurolingwistyka, Kurcz I., Okuniewska H. (eds.), Wydawnictwo SWPS, Warsaw, 2011, p. 39.

7 B. Bernstein, "Social structure, language and learning", Educational Research, vol. 3, 1961, pp. 163-176.

8 A. Rakowska, Jezyk, komunikacja, niepetnosprawność. Wybrane zagadnienia, Wydawnictwo Naukowe AP, Cracow, 2003, p. 71.

${ }_{9}^{9}$ I. Kurcz, “Kompetencja językowa i kompetencja komunikacyjna: ich uwarunkowania biologiczne i społeczne. Model wiedzy językowej człowieka”, [in:] Język jako przedmiot badań psychologicznych. Psycholingwistyka ogólna i neurolingwistyka, Kurcz I., Okuniewska H. (ed.), Wydawnictwo SWPS, Warsaw, 2011, p. 39.

${ }^{10}$ Cf. e.g. M. Adamczyk-Borucka, “Sprawność językowa dzieci ośmioletnich. Porównanie zdolności językowych dziewcząt i chłopców w normie intelektualnej”, 


\section{intellectual disability the literature is rather poor. ${ }^{11}$ Based on these scarce literature resources, the image of language competence of}

Szkoła Specjalna, no. 4, 2013, pp. 270-279; K. Borawska-Kalbarczyk, Umiejętności językowe dziecka kończącego edukację wczesnoszkolna, Trans Humana, Białystok, 2004; A. Dziurda-Multan, Dziecięce sposoby tworzenia nazw, Wydawnictwo Katolickiego Uniwersytetu Lubelskiego, Lublin. 2008; E. Filipiak, Aktywność językowa dzieci w wieku wczesnoszkolnym, Wydawnictwo Uczelniane WSP, Bydgoszcz, 1996; A. Giermakowska, “Ocena kompetencji słowotwórczej uczniów z trudnościami w czytaniu i pisaniu na poziomie edukacji wczesnoszkolnej”, Szkoła Specjalna, no. 5, 2012, pp. 356-366; S. Grabias, Z badań nad sprawnościa językowa dzieci, Provincial and Municipal Public Library, Zamość, 1981; A. Jakubowicz-Bryx, Kompetencje leksykalne uczniów w edukacji wczesnoszkolnej, Wydawnictwo Uniwersytetu Kazimierza Wielkiego, Bydgoszcz, 2006; J. Malendowicz, O poprawność pisemnych wypowiedzi uczniów klas I-IV, WSiP, Warsaw, 1974; H. Małkowska-Zegadło, Rozwój języka mówionego i pisanego uczniów w wieku 8-11 lat, Wydawnictwa Szkolne i Pedagogiczne, Warsaw, 1983; M. Mnich, Sprawność językowa dzieci w wielu wczesnoszkolnym, Oficyna Wydawnicza Impuls, Cracow, 2002; F. Nowak, "Błędy fleksyjne i słowotwórcze w pracach pisemnych uczniów szkół podstawowych", Jezzyk Polski w Szkole: dla klas IV-VIII, vol. 4, 1990/1991, pp. 97-106; F. Nowak, "Błędy językowe w zakresie kompozycji zdania złożonego”, Język Polski w Szkole: dla klas IV-VIII, vol. 2/3, 1990/1991, pp. 74-77; E. Polański, "Błędy leksykalne uczniów klas IV-VIII. Part 1", Jezzyk Polsk i w Szkole: dla klas IV-VIII, vol. 2, 1981/1982, pp. 75-80; E. Polański, “Błędy leksykalne uczniów klas IV-VIII. Part 2", Język Polsk i w Szkole: dla klas IV-VIII, vol. 4, 1981/1982, pp. 65-82; E. Polański, O. Przybyła, “Odstępstwa od normy językowej u uczniów w zintegrowanym kształceniu wczesnoszkolnym", Nauczyciel i Szkoła, no. 3/4, 2002, pp. 185-195; Z. Saloni, Błędy językowe w pracach pisemnych uczniów liceum ogólnoksztatcacego. Próba analizy językoznawczej, Państwowe Zakłady Wydawnictw Szkolnych, Warsaw, 1971; R. Stawinoga, Twórczość językowa dziecka w teorii i praktyce edukacyjnej, Wydawnictwo Uniwersytetu Marii Curie-Skłodowskiej, Lublin, 2007; U. Wińska, Błędy językowostylistyczne uczniów szkót podstawowych województwa gdańskiego, part I-II, WSP, Gdańsk, 1966; M. Żytko, Pozwólmy dzieciom mówić i pisać - w kontekście badań umiejętności językowych trzecioklasistów, Central Examination Commission, Warsaw, 2010.

11 J. Bałachowicz, J. Paluszewski (ed.), Sprawności językowe dzieci upośledzonych umystowo w stopniu lekkim, Wydawnictwo WSPS, Warsaw, 1995; J. Błeszyński, Nie(petno)sprawność intelektualna. Mowa, język, komunikacja. Czy iloraz inteligencji wyjaśnia wszystko?, Wydawnictwo Harmonia, Gdańsk, 2013; K. Kaczorowska-Bray, Wyrażenia przyimkowe w mowie dzieci z upośledzeniem umystowym w stopniu umiarkowanym i lekkim, Wydawnictwo Harmonia, Gdańsk, 2013; K. Kaczorowska-Bray, Kompetencja i sprawność językowa dzieci z niepetnosprawnością intelektualna w stopniu znacznym, umiarkowanym i lekkim, Wydawnictwo UG, Gdańsk, 2017; M. Michalik, Diagnozowanie kompe- 
people with intellectual disability is as follows: the increase in words does not translate into a spontaneous increase in the number of their combinations in the syntax of sentences, difficulties in learning and applying the rules governing the language, a low degree of grammatical correctness of speech, less frequent use of adjectives, adverbs, pronouns, numerals, conjunctions, prepositions, a slower pace of learning and assimilating various verbal behaviours, monotonous production of structures of a particular type, long persistence of morphological and syntactic errors, selective assimilation of sentence patterns, inconsistent application of syntactic rules. ${ }^{12}$ In the context of the article, it is worth paying attention to three conclusions resulting from research conducted by Jacek Błeszyński regarding the development of grammar and spelling skills, which are used by people with a mild intellectual disability and attempts to compare acquired language skills to the developmental norm. ${ }^{13}$ The author based on the analysis of written works of the third grade students of junior high

tencji lingwistycznej ucznia szkoły specjalnej, Wydawnictwo Naukowe AP, Cracow, 2006; M. Michalik, Kompetencja składniowa w normie i w zaburzeniach, Wydawnictwo Naukowe UP, Cracow, 2011; J. Piekarska, Błędy językowe uczniów z inteligencją niższą niż przeciętna, Difin, Warsaw, 2015; Z. Tarkowski, “Agramatyzm u uczniów lekko upośledzonych umysłowo", [in:] Rewalidacja dzieci ze złożonymi upośledzeniami, Sękowska Z. (ed.), Wydawnictwo UMCS, Lublin. 1988, pp. 81-108; A. Wątorek, Kompetencja językowa uczniów z lekką niepetnosprawnością intelektualna, Wydawnictwo Nomos, Cracow, 2014.

12 J. Błeszyński, Nie(petno)sprawność intelektualna. Mowa, język, komunikacja. Czy iloraz inteligencji wyjaśnia wszystko?, Wydawnictwo Harmonia, Gdańsk, 2013, p. 100, 103, 109, 111; I. Chrzanowska, Funkcjonowanie dzieci upośledzonych umysłowo w stopniu lekkim w szkole podstawowej, Wydawnictwo UŁ, Łódź, 2003, p. 55; A. Rakowska, Jezyk, komunikacja, niepetnosprawność. Wybrane zagadnienia, Wydawnictwo Naukowe AP, Cracow, 2003, p. 127, 129; Z. Tarkowski, “Zaburzenia mowy dzieci upośledzonych umysłowo", [in:] Logopedia - pytania i odpowiedzi. Podręcznik akademicki, vol. 2. Zaburzenia komunikacji językowej u dzieci i osób dorostych, Gałkowski T., Jastrzębowska G. (ed.), second edition extended and amended, Wydawnictwo UO, Opole, 2003, s. 205-206; Zbigniew Tarkowski, Mowa osób upośledzonych umysłowo i jej zaburzenia, [in:] Podstawy neurologopedii, Gałkowski T., Szeląg E., Jastrzębwska G. (eds.), Wydawnictwo UO, Opole, 2005, p. 561; A. Wątorek, Kompetencja językowa uczniów z lekka niepetnosprawnością intelektualna, Wydawnictwo Nomos, Cracow, 2014, p. 69.

13 J. Błeszyński, Nie(petno)sprawność intelektualna. Mowa, język, komunikacja. Czy iloraz inteligencji wyjaśnia wszystko?, Wydawnictwo Harmonia, Gdańsk, 2013, p. 79, 80. 
school in terms of grammatical (inflectional and syntactic), lexical (meaning, phraseological and word-formation), stylistic, as well as spelling and punctuation errors stated that a) students with intellectual disabilities made mostly spelling and punctuation errors, and then in descending order: stylistic, lexical and grammatical errors. There were no phraseological errors in the works. Statistically significant differences in the number of errors made in various forms of written assignments are visible in the case of inflectional, lexical, word-formation and spelling errors; b) errors in the work of students with intellectual disabilities and normal ones are similar in terms of quantity, though disproportionately; c) students with a mild intellectual disability make similar errors to normal students. ${ }^{14}$

To summarise up, the problem discussed in the article concerning a qualitative description of errors made by students with a mild intellectual disability has not been the subject of a scientific description from a linguistic point of view. It should be added that in the article, because of its limited volume, the Author only wants to signal the problem.

\section{Research methodology}

The study of linguistic errors made by students of special schools with a diagnosed mild intellectual disability conducted by the Author remains within one of the two research trends concerning the linguistic functioning of people with intellectual disability. This is so far the most established and dominant trend, encouraging to treat these people as individuals with a set of multiple deficits, which, according to J. Bałachowicz and J. Paluszewski, sets the direction of scientific activities in the sphere of language and speech of people with intellectual disabilities, bringing them to [...] documentation of deficits and conditions, presentation of weak points and diffi-

14 J. Błeszyński, Nie(petno)sprawność intelektualna. Mowa, język, komunikacja. Czy iloraz inteligencji wyjaśnia wszystko?, Wydawnictwo Harmonia, Gdańsk, 2013, p. 100, 103, 109. 
culties [...] in using the language compared to people with normal development. ${ }^{15}$

The aim of the article is to analyse linguistic errors excerpted from written works of students with a mild intellectual disability educated at the second stage of education (in grades IV-VIII) and to answer the following questions: 1) What kind of language mistakes are made by students with mild intellectual disability?; 2) Are there any qualitative differences in their mistakes, compared to those of students characterised by a typical development? The answer to the second question is important, as it should be emphasised that students of special schools with a mild intellectual disability follow the same general education program as students of public schools. 16 These students are required to take tests of the same level of difficulty as the students within the intellectual norm.

60 works of students with intellectual disabilities and 60 works of students with typical development were analysed. These were classwork, independent work performed during lessons, and correction of classwork. The study was conducted in the school year $2018 / 2019$ in one of the special school and education centres in the Łódź Voivodeship. Two groups of students (the study and control group) were selected, taking into account not the chronological or mental age, but the criterion of the educational level. The study group (30 students, including 15 girls and 15 boys) consisted of students with an opinion from a psychological and pedagogical counselling centre confirming their mild intellectual disability. The control group (30 students, including 15 girls and 15 boys) were students with typical development, attending one of the primary schools in the Łódź Voivodeship. All subjects came from complete families, and their parents had vocational education, in 5 cases elementary education.

15 J. Bałachowicz, J. Paluszewski (ed.), Sprawności językowe dzieci upośledzonych umystowo w stopniu lekkim, Wydawnictwo WSPS, Warsaw, 1995, p. 5.

16 The Act of 14 December 2016. The Educational Law (Journal of Laws of $2018 \mathrm{r}$. item 996 as amended) - The Act of 14 December 2016 The Educational Law (Journal of Laws of 2018 item 996 as amended) - art. 127 paragraph 3.art. 127 paragraph 3. 
The term linguistic error used in the paper needs to be clarified. The concept of linguistic error in linguistics is one of the basic concepts of proper language use and, according to Józef PorayskiPomsta, has been sufficiently described in the source literature. ${ }^{17}$ Several exemplary definitions of a linguistic error are as follows: cf. a linguistic error is an unconscious departure from the linguistic norm currently in force, or such an innovation that has no justification: it does not improve communication, does not express new content, does not present again, in another way the emotions of the narrator etc. ${ }^{18}$ An error can also be defined as a way of using some element of a language that shocks its conscious users, because it is in conflict with their previous habits, and is not functionally explained. ${ }^{19}$ According to the definition presented in Encyklopedia jezzykoznawstwa ogólnego [Encyclopaedia of general linguistics] (EJO) by Zdzisław Saloni, a linguistic error will include all language uses that do not comply with the accepted linguistic norm and indicate a violation of the basic principles imposed by the system. ${ }^{20}$

A tendency to avoid this term in relation to childhood speech has been visible since the late 1980s. Some researchers suggest alternative forms such as unconventional forms, innovations, deviations from the norm, specific forms, childhood new-coined words etc. ${ }^{21}$ However, as

17 J. Porayski-Pomsta, "Kultura języka”, [in:] Nauka o języku dla polonistów, Dubisz S. (ed.), Wydawnictwo Książka i Wiedza, Warsaw, 1996, p. 89.

18 A. Markowski, Nowy stownik poprawnej polszczyzny, PWN, Warsaw, 1999, p. 1621; A. Markowski, Kultura języka polskiego. Teoria. Zagadnienie leksykalne, PWN, Warsaw, 2005, pp. 55-60.

${ }^{19}$ A. Markowski, Nowy stownik poprawnej polszczyzny, PWN, Warsaw, 1999, p. 1621; A. Markowski, Kultura języka polskiego. Teoria. Zagadnienie leksykalne, PWN, Warsaw, 2005, p. 55.

${ }^{20}$ sv. linguistic error in EJO - Encyklopedia językoznawstwa ogólnego, Polański K. (ed.), second edition, Ossolineum, Warsaw, 1999, p. 77.

${ }^{21}$ M. Smoczyńska, "Metodologiczne problemy analizy błędów językowych dzieci", [in:] Wiedza a język, vol. 2. Jezyk dziecka, Kurcz I., Shugar G.W., Bokus B. (eds.), PAN, Wrocław-Warsaw-Cracow-Gdańsk-Łódź, 1987, pp. 95-116; E. Kozłowska, "Fleksja podstawowych kategorii wyrazów w mowie dzieci pięcioletnich (deklinacja)", Poradnik Jezykowy, vol. 9/10, 1991, pp. 399-406; J. Porayski-Pomsta, 
emphasised (and at the same time further justified) by Agnieszka Watorek, although the use of a problematic term in the context of immature verbal productions can be misleading, its rigid substitution with another term rather multiplies than cuts doubt. ${ }^{22}$ Therefore, in the paper the Author uses a term of a linguistic error, ${ }^{23}$ understanding it in this case as a deviation from the norm, which is a result of immature thinking, limited efficiency in the use of speech and being based on false assumptions. ${ }^{24}$

In this paper, the basis for the analysis of linguistic errors will be the classification of Andrzej Markowski25 with small supplements from the classification of Zygmunt Saloni. ${ }^{26}$ Because of the limited volume of the paper, it will be limited to the discussion of grammatical and lexical errors.

A researcher can distinguish between interlingual and intralingual errors. Interlingual errors are writing errors: spelling and punctuation errors. They are related to the structure of the language, but do not violate system rules or language development principles. Intralinguistic errors that directly violate system rules can be further divided into system (language) and usage (or stylistic) errors. Language errors include grammatical, lexical and phonetic errors. ${ }^{27}$

"O tzw. błędach językowych dzieci", Wychowanie w Przedszkolu, vol. 8, 2002, p. 1; E. Łuczyński, Kategoria przypadka w ontogenezie jezzyka polskiego, czyli o wchodzeniu dziecka w rzeczywistość gramatyczna, Wydawnictwo UG, Gdańsk, 2004.

22 A. Wątorek, Kompetencja językowa uczniów z lekką niepetnosprawnościa intelektualna, Wydawnictwo Nomos, Cracow, 2014, p. 85.

${ }^{23}$ This term is used by, among others, J. Błeszyński, J. Piekarska, A. Wątorek (cf. the items cited above).

${ }^{24}$ A. Wątorek, Kompetencja językowa uczniów z lekka niepetnosprawnością intelektualna, Wydawnictwo Nomos, Cracow, 2014, p. 86.

${ }^{25}$ A. Markowski, Kultura jezzyka polskiego. Teoria. Zagadnienie leksykalne, PWN, Warsaw 2005, pp. 55-60.

${ }^{26}$ Z. Saloni, Błędy językowe w pracach pisemnych uczniów liceum ogólnokształcacego. Próba analizy jezzkoznawczej, Państwowe Zakłady Wydawnictw Szkolnych, Warsaw, 1971, pp. 36-111.

27 A. Markowski, Kultura jezyka polskiego. Teoria. Zagadnienie leksykalne, PWN, Warsaw, 2005, pp. 55-56. 


\section{Types of errors made by students with mild intellectual disability (LNI) and students with normal development (TR)}

\section{Grammatical errors}

1.1. Inflectional errors, or errors that violate the norm in terms of inflection of words, excerpted from written works of students, result from:

a) the choice of a wrong form of a word:

LNI: Muj kolega ma duże ucha (instead of uszy). [My friend has big ears. ${ }^{28}$ ] Patszył szeroko otfartymi okami (instead of oczami) [He stared wide-eyed.] Mamy z bratem polskie imienia (instead of imiona). [Me and my brother have Polish names.] Byłem zmenczony i szybko zasnełem (instead of zasnąłem). [I was tired and fell asleep soon.] On sie ze mnie wyśmiewywuje (instead of wyśmiewa). [He makes fun of me.];

TR: Nauczyciel wytargał ucznia za ucha (instead of uszy). [The teacher pulled the ear of the student.] Kiedy niewykonywuje poleceń rodziców, dostaję karę (instead of wykonuję). [When I do not obey my parents, I get punished.] Mój brat jak dostaje nowom zabawke to podskakiwuje $\mathrm{z}$ radości (instead of podskakuje). [When my brother gets a new toy, he jumps with joy.]

b) the choice of a wrong declension pattern:

LNI: Czekolada jest słotka, a cukier jeszcze bardziej słotki (instead of słodszy). [Chocolate is sweet and sugar is even sweeter.] Pani jest najbardziej piękniejsza od innych (instead of najpiękniejsza). [The lady is more beautiful than others.] Mieliśmy najkolorofsze ubrania (instead of najbardziej kolorowe). [We had the most colourful clothes.] Pies jest zły, wilk zlejszy, a tygrys najzlejszy (instead of

28 The examples are cited using their original spelling. Because the article is focused on qualitative rather than quantitative analysis, specific types and subtypes of errors are presented using 2-5 examples. As for the criterion for the selection of examples, the cited examples include those understandable for people without linguistic background. 
bardziej zły, najbardziej zły) [The dog is bad, the wolf is worse and the tiger is worst];

TR: Moja najulubieńsza koleżanka dała mi prezent (instead of najbardziej ulubiona). [My favourite friend gave me a present.] On jest dla mnie najbardziej ważniejszy (instead of najważniejszy). [He is the most important for me.] Kupiłem najżułciejsze cytryny (instead of najbardziej żółte) [I bought the most yellow lemons];

c) the choice of a wrong form of the inflexion stem:

LNI: Spotkałem się z mojimi dziadekami (instead of dziadkami). [I met my grandparents.] Wybuch kotł (instead of kocioł). [A boiler exploded.] Wyszłem wcześniej z szkoły (instead of wyszedłem) [I left school earlier];

TR: Poszłem z kolegami do kina (instead of poszedłem). [I went to the cinema with my friends.] Ona go kopła tak mocno, że płakał (instead of kopnęła). [She kicked him so strongly that he cried.] Chłopcy ciągli dziewczyny za włosy (instead of ciągnęli) [Boys pulled girl's hair.];

d) the choice of a wrong desinence:

LNI: Fszystkich wsadzono do wagona (instead of wagonu). [Everyone was placed in a railway carriage.] Bohater potszet do stoła (instead of stołu). [The protagonish approached the table.] Kolega ulek fczoraj wypadku (instead of wypadkowi). [My friend had an accident yesterday.] Kobieta podała chłopcowi wode (instead of chłop$\mathrm{cu}$ ). [The woman gave water to the boy.] Dziewczyny z naszej klasy umią grać w piłke nożnom (instead of umieją). [Girls from our form can play football.]

TR: Padał deszcz i na dworzu nie było ludziów (instead of ludzi). [It was raining and there was no people outside.] Musieliśmy nauczyć się tych wierszów (instead of wierszy) na pamięć. [We had to learn these poems by heart.] Na starcie staneło dziesięć chłopców (instead of dziesięciu). [Ten boys stood at the start line.] Ciąg mocniej za sznurek, krzyknoł do kolegi (instead of ciągnij) [He shouted to his friend to pull stronger the line.]; 
e) no declension of a word, which has its own declension pattern: LNI: Dzień dobry, pani Ania (instead of: pani Aniu). [Good morning, Mrs. Ania.] Jade na wakacje do Sopot (instead of Sopotu). [I go on holiday to Sopot.]

TR: Adam Mickiewicz napisał „Pan Tadeusz" (instead of "Pana Tadeusza") [Adam Mickiewicz wrote "Pan Tadeusz".] Obejżeliśmy w klasie "Zemsta" Fredry (instead of "Zemstę"). [We watched “Zemsta” by Fredro in the classroom.] W „Mały Książę" jest wiele myśli do zapamiętania (instead of "Małym Księciu") [There are many thoughts to remember in "The little prince".];

f) declension of a word, which cannot be attributed with a declension pattern:

LNI: Nie lubie kakała (instead of kakao). [I do not like cocoa.] Muj brat chodzi do technika (instead of technikum). [My brother attends a tehnical school.]

TR: Wypiła kubek kakała (instead of kakao) i zjadła bułke. [She drank a cup of cocoa and ate a bread roll.] Moja siostra chodzi do solaria (instead of solarium) i jest opalona. [My sister goes to a solarium and is tanned.]

1.2. Syntactic errors. They consist in choosing a wrong syntactic pattern, or a wrong combination of word forms into units of a text. Errors excerpted from written works concern:

a) errors in the area of agreement:

LNI: Podwórka dziatka pilnowali dwa psy (instead of pilnowały dwa psy). [The yard of the grandfather was guarded by two dogs.] Dziewczyny umieli już szyć (instead of dziewczyny umiały). [The girls could already sew.] Nauczyciele chcom by dzieci umieli ich przedmiot najlepiej (instead of dzieci umiały). [Teachers want children to know their subject best.]

TR: Wszyscy dzieci kibcowali podczas zawodów swoim reprezentantom (instead of wszystkie dzieci kibicowały). [All children supported their representatives during the competition.] Wiele utworów jest poświęcone wojnie (instead of jest poświęconych). [Many compositions are devoted to war.] Dzieci mieli się wkrótce 
dowiedzieć o wycieczce (instead of dzieci miały). [The children were soon to learn about the trip.]

b) errors in the area of case government:

LNI: On stał sie człowiek spokojny (instead of stał się spokojnym człowiekiem). [He became a calm person.] Chłopak postanowił otszukać swojej rodziny (instead of odszukać swoją rodzinę). [The boy decided to find his family]. Pszyjaciel zawsze dotrzymuje słowo (instead of dotrzymuje słowa). [The friend always keeps his word.]

TR: U nas w szkole zakazali nosić kolorowych ubrań (instead of zakazali nosić kolorowe ubrania). [At our school it was forbidden to wear colourful clothes.] Byliśmy grzecznymi i dostaliśmy nagrodę (instead of byliśmy grzeczni). [We were good and we were rewarded.] On pilnował swoją pracę, bał się zwolnienia (instead of swojej pracy). [He minded his job, was afraid of being fired.] Rodzice zawsze mówili, że papierosy palić nie wolno (instead of papierosów). [Parents always repeated that smoking was not allowed.];

c) errors in using prepositions:

LNI: Latem jeździmy do działki nad może (instead of na działkę). [In summer, we go to our allotment garden by the sea.] Powodem dla płaczu była jedynka z matematyki (instead of powodem pła$\mathrm{czu}$ ). [The reason for crying was an $\mathrm{F}$ in mathematics.]

TR: Moja mama pracuje na kasie $\mathrm{w}$ markecie (instead of $\mathrm{w}$ kasie). [My mother works at the cash register in a supermarket.] Lubię truskawkową pastę dla zębów (instead of do zębów). [I like strawberry toothpaste.] Oni pojechali na podróż poślubną (instead of w podróż); [They went on honeymoon.]

d) errors in using conjunctions and relative pronouns:

LNI: Dostałem jedynke, ale mama będzie zła (instead of więc). [I got an F, so my mom will be angry.] Byłem na wycieczce, gdzie byliśmy w Makdonaldzie (instead of na której) [I was on a trip during which we visited a McDonald's.];

TR: Wybiorę technikum, gdzie po jego skończeniu szybko dostanę pracę (instead of gdyż, ponieważ). [I will choose a technical school, 
as after finishing it, I will quickly get a job.] Była sierotą, ale musiała pracować na życie (instead of więc). [She was an orphan, so she had to work for a living.]

e) incorrect syntax shortening:

LNI: Warto interesować sie i oglądać programy pszyrodnicze (instead of warto interesować się programami przyrodniczymi i je oglądać). [It is worth to be interested in and watch nature documentaries.] Źle zachowywała się młodzież przed i po koncercie (instead of przed koncertem i po nim) [Young people behaved badly before and after the concert.];

TR: Czytając książkę używamy i rozwijamy naszą wyobraźnię (instead of używamy naszej wyobraźni i ją rozwijamy). [When reading a book, we use our imagination and develop it.] Miał ojca, nałogowego pijaka, który znęcał się i kłócił z synem (instead of znęcał się nad synem i kłócił z nim). [He had a father, a heavy drunkard, who ill-treated his son and argued with him.] Troszczył się i opiekował swoim przyjacielem (instead of troszczył się o swojego przyjaciela i opiekował się nim) [He took care of his friend and looked after him.];

f) incorrect constructions with participle elliptical sentences:

LNI: Będąc w ósmej klasie polubiłem polski (instead of kiedy byłem w ósmej klasie). [When I was in the eighth grade, I became fond of Polish.] Został pszyłapany kradnąc wiśnie (instead of kiedy kradł wiśnie) [He was caught when he was stealing cherries.];

TR: Myjąc się wypadł mi z ręki prysznic i opryskał całą łazienkę (instead of kiedy się myłem). [When I was taking a shower, the shower fell out of my hand and sprayed whole bathroom.] Jadąc przez miasto przebiegło nam drogę dziecko (instead of kiedy jechaliśmy przez miasto) [When we were driving through the city a child ran our way.];

g) constructions incorrect in terms of word order:

LNI: Dużo bym chciał dostać prezentów pod choinkę (instead of chciałbym dostać dużo). [I would like to get a lot of presents for 
Christmas.] Dzieci zmenczone ogarnoł sen (instead of zmęczone dzieci) [Tired children fell asleep.];

TR: Samodzielności ona się nauczyć musiała (instead of ona musiała nauczyć się samodzielności). [She had to learn independence.] Ogród ciekawił bardzo dziewczynkę, który nie miał furtki i był obrośnięty bluszczem (instead of ogród, który nie miał furtki i był obrośnięty bluszczem, bardzo ciekawił dziewczynkę). [The garden, which had no wicket and was covered with ivy, was very interesting for the girl.]

2. Lexical errors

2.1. Meaning (word) errors. In the case of investigated students, they concern:

a) using words in the wrong sense (unnecessary neosemantisms):

LNI: Ona ożeniła się z synem sąsiada (instead of wyszła za mąż). [She became a husband of a son of her neighbour (instead of she became a wife).] Oddali babci dziecko do chowu (instead of do wychowania). [They gave the child to the grandmother to breed it (instead of to raise it).]

TR: Burza narastała $\mathrm{z}$ minuty na minutę (instead of nasilała się). [The storm was growing every minute (instead of the storm was rising).] Kiedyś chciałem pozostać marynarzem (instead of zostać marynarzem) [Once I wanted to remain a sailor (instead of to become a sailor).];

b) confusing meanings of words that are similar in terms of sound or morphology:

LNI: Dawniej na wsi panowało zaciemnienie (instead of ciemnota). [People in the country used to be ignored (instead of ignorant).] Gagarin był kosmitą (instead of kosmonautą). [Gagarin was a cosmos (instead of a cosmonaut).] Rok przestępczy ma 366 dni (instead of przestępny). [A lip year has 366 days (instead of a leap year).] Jak żyli ludzie pierworodni? (instead of pierwotni). How did primary humans live? (instead of primitive). Jego ojciec był bardzo chorobliwy (instead of chorowity) [His father is very sick (instead of sickly).]; 
TR: w filmie wykorzystano wiele tryków (instead of trików). [In the movie, many trikes were used (instead of tricks).] Seriale są odcinkowe i mają wiele wątków ubocznych (instead of pobocznych). [Serial films have parts and many side scenes (instead of side scenarios).] Jego pasja koligowała z nauką (instead of kolidowała) [His passion interrelated with learning (insead of interfered).];

c) using pleonasms:

LNI: W Polsce jest dużo zagranicznych cudzoziemców (instead of cudzoziemców). [There a lot of foreign foreigners in Poland (instead of foreigners).] Zrobiliśmy z chłopakami głupie głupstwo (instead of głupstwo). [Me and my buddies did a stupid stupidity (instead of stupidity).] Poprawiłem się na lepsze (instead of poprawiłem się). [I have improved for the better (instead of I have improved).] Podskakiwałem do góry $\mathrm{z}$ radości (instead of podskakiwałem) [I jumped up upwards with joy (instead of I jumped up with joy).]; TR: Moim własnym zdaniem każde dziecko powinno mieć wakacje (instead of moim zdaniem). [In my own opinion each child should have a holiday (instead of in my opinion).] Staś i Nel kontynuowali dalej podróż (instead of kontynuowali podróż) [Staś and Nel further continued their journey (instead of continued their journey).];

d) violation of collocation:

LNI: Czcili bogów tak, że dawali im ukłony (instead of oddawali ukłony). [They worshipped their gods so that they gave bows to them (instead of bowed to them).] Ksiąszka daje ciekawość (instead of wzbudza ciekawość) [The book gives curiosity (instead of arouses curiosity).];

TR: Nie bał się postawić czoła wrogowi (instead of stawić czoła). [He was not afraid to give face to the enemy (instead of face).] Wojska wroga odniosły porażkę (instead of poniosły porażkę). [Enemy troops achieved a defeat (instead of sustained a defeat).]

e) errors in the use of pronouns and other words of a relationalgrammatical meaning:

LNI: Utwory Kochanowskiego wyrażają one stosunek poety do świata (instead of wyrażają stosunek). [Compositions of Kochanowski 
they express the attitude of the poet to the world (instead of compositions of Kochanowski express).] Kochanowski po śmierci jego ukochanej córki napisał cykl trenów (instead of po śmierci ukochanej córki) [Kochanowski after the death of his own beloved daughter wrote a series of threnodies (instead of his beloved daughter).]; TR: Był miszczem w jego dyscyplinie (instead of w swojej). [He was an expert in their discipline (instead of his).] Ale ta dziewczynka, kiedy wyszła z tej szkoły, nie poszła do domu (instead of ale dziewczynka, ze szkoły). [But that girl who left that school, did not go home (instead of the girl, school).]

2.2. Phraseological errors. The use of phrasemes non-compliant with the norm in the analysed works applies to the following issues:

a) a change in phraseme form as a result of exchange, reduction or supplementation of the composition of the phraseme:

LNI: On wywierał znaczenie (instead of wywierał wpływ). [He exerted meaning (instead of exerted influence).] Król decyduje o wszystkim i ma ostatnie zdanie (instead of ma ostatnie słowo). [The king decides about everything and has the last sentence (instead of the last word).] Na tronie panował Bolesław Krzywousty (instead of na tronie zasiadał) [Bolesław III Wrymouth ruled on the throne (instead of was on the throne).];

TR: Napis nie zrobił dużej reakcji na nauczycielu (instead of nie zrobił dużego wrażenia). [The inscription did not make a big reaction on the teacher (instead of did not make a big impression).] Przeszła w życiu wiele krzywd (instead of doznała wielu krzywd). [She has suffered much harm in her life (instead of she has suffered).]

b) a change in phraseme form as a result of the change in the grammatical form of one of the components:

LNI: Na lekcjach siedzę jak strusia (instead of jak trusia). [During the class I sit as an ostrich (instead of I sit timidly).] Byli tacy ludzie, którzy stawiali opory (instead of stawiali opór) [There were people who made resistances (instead of who resisted).]; 
TR: Wymieniliśmy pare słów ze sobą (instead of zamienilismy) [We changed a few words with each other (instead of we exchanged).] W wakacje spotkała mnie przygoda zamrażająca krew w żyłach (instead of mrożąca krew w żyłach). [In the summer, I experienced an adventure which refrigerated my blood (instead of made my blood run cold).]

2.3. Word-formation errors in the analysed student works concern:

a) using a wrong formant:

LNI: Pracował jako cieślarz (instead of cieśla). [He worked as a carpenter.] Nad morzem było dużo plażowników (instead of plażowiczów). [There were a lot of sunbathers by the sea.] Rycerze brali udział $\mathrm{w}$ wielu walczeniach (instead of walkach). [Knights took part in many fightings (instead of many fights).] Przecierając kszemień o kszemień rozpalali ogień (instead of pocierając) [Passing a flint against a flint against, they started a fire (instead of rubbing).];

TR: On nie był uszczycony tym zaproszeniem (instead of zaszczycony). [He was not honoured by this invitation.] To był przydomny ogródek (instead of przydomowy). [It was a backyard garden.] Woda była źródłowa (instead of źródlana) [This was source water (instead of spring water).];

b) choosing a wrong word formation stem:

LNI: Po wymarnięciu dynastii Piastów byli Jagielonowie (instead of wymarciu). [After the dying of the Piast dynasty, there were The Jagiellonians ruled.] Miałem zadzierki ze swoim kolegom (instead of zatargi). [I had splinters with my friend (instead of a conflict).] W piramidach były zmylne korytarze (instead of ślepe) [There were dead-end corridors in the pyramids.]29;

TR: Podczas bycia w więzieniu myślał o ucieczce (instead of poby$\mathrm{tu}$ ). [During his being in prison he was thinking about the escape

29 The last two examples are typical neologisms that could be classified as morphological errors (according to the classification of Z. Saloni). 
(instead of his stay).] W telewizji wiadomościarze (instead of dziennikarze) mówili o wypadku. [On TV, newspeople (instead of journalists) talked about the accident.]

\section{Summary}

1. Linguistic errors were present in the works of all students with a mild intellectual disability.

2. When assessing the language competence of students with a mild intellectual disability, it should be emphasised that the spectrum of incorrect linguistic behaviour of students covers all types of errors.

3. Inflectional errors are related to, among others, unusual and irregular inflexion, the wrong selection of declension and conjugation endings because of failure to consider such factors as: phonetic (words whose stems end with soft and hard consonants differ in inflexion), semantic (personal nouns and animate impersonal nouns have differ endings), customary ones or those associated with the wrong inflexion pattern. Students with mild intellectual disability have a problem with the comparison of adjectives or use of collective numerals.

4. Syntactic errors of students with mild intellectual disability consist in incorrectly combining word forms into units of text. Students do not take into account the fact that these forms combine into syntactic relations, or e.g., in the relations of agreement (the primary element imposes its grammatical properties, e.g. type on the secondary element), case government (the primary element imposes a specific inflexion form on the secondary element, e.g. odszukać kogo? [to find whom?] rodzine [family]). They also have problems with the correct use of prepositions, conjunctions and relative pronouns. They create incorrect constructions in terms of word order, or use incorrect syntax shortening.

5. Meaning errors in students with a mild intellectual disability mainly result from confusing meanings that are similar in sound or 
morphology (or in structure), and from using words in the wrong sense. The analysed students sometimes violate collocation, as well as use pleonasms (or expressions known in Polish as "buttered butter").

6. Phraseological errors, difficult for children with mild intellectual disability, also for the fact that they are wide-spread in the language word connections used in their entirety and their meaning is not the sum of the meanings of the words that make up a phraseme, they mainly concern the change in the form of phrasemes because of an exchange, reduction or supplementation of phraseme composition or change in the grammatical form of one of its components.

7. In turn, word-formation errors, involve either using a wrong formant or a wrong word formation stem.

8. Students with mild intellectual disability make similar errors as students with typical development. There were no qualitative differences between the study group and the control group.

9. Specific conclusions can be made after conducting in-depth and larger-scale research.

\section{References}

Adamczyk-Borucka M., "Sprawność językowa dzieci ośmioletnich. Porównanie zdolności językowych dziewcząt i chłopców w normie intelektualnej", Szkoła Specjalna, no. 4, 2013, pp. 270-279.

Bałachowicz J., Paluszewski J. (ed.), Sprawności językowe dzieci upośledzonych umystowo w stopniu lekkim, Wydawnictwo WSPS, Warsaw, 1995.

Bernstein B., "Social structure, language and learning", Educational Research, vol. 3, 1961, pp. 163-176.

Błeszyński J., Nie(petno)sprawność intelektualna. Mowa, jezyk, komunikacja. Czy iloraz inteligencji wyjaśnia wszystko?, Wydawnictwo Harmonia, Gdańsk, 2013.

Borawska-Kalbarczyk K., Umiejętności językowe dziecka kończacego edukację wczesnoszkolna, Trans Humana, Białystok, 2004.

Chrzanowska I., Funkcjonowanie dzieci upośledzonych umystowo w stopniu lekkim w szkole podstawowej, Wydawnictwo UŁ, Łódź, 2003.

Dziurda-Multan A., Dziecięce sposoby tworzenia nazw, Wydawnictwo Katolickiego Uniwersytetu Lubelskiego, Lublin, 2008. 
EJO - Encyklopedia językoznawstwa ogólnego, Polański K. (ed.), second edition, Ossolineum, Warsaw, 1999.

Filipiak E., Aktywność językowa dzieci w wieku wczesnoszkolnym, Wydawnictwo Uczelniane WSP, Bydgoszcz, 1996.

Giermakowska A., “Ocena kompetencji słowotwórczej uczniów z trudnościami w czytaniu i pisaniu na poziomie edukacji wczesnoszkolnej”, Szkoła Specjalna, no. 5, 2012, pp. 356-366.

Grabias S., Z badań nad sprawnościa językowa dzieci, Provincial and Municipal Public Library, Zamość, 1981.

Jakubowicz-Bryx A., Kompetencje leksykalne uczniów w edukacji wczesnoszkolnej, Wydawnictwo Uniwersytetu Kazimierza Wielkiego, Bydgoszcz, 2006.

Kaczorowska-Bray K., Wyrażenia przyimkowe w mowie dzieci z upośledzeniem umystowym w stopniu umiarkowanym i lekkim, Wydawnictwo Harmonia, Gdańsk, 2013.

Kaczorowska-Bray K., Kompetencja i sprawność językowa dzieci z niepetnosprawnościa intelektualna w stopniu znacznym, umiarkowanym i lekkim, Wydawnictwo UG, Gdańsk, 2017.

Kozłowska E., "Fleksja podstawowych kategorii wyrazów w mowie dzieci pięcioletnich (deklinacja)", Poradnik Jezykowy, vol. 9/10, 1991, pp. 399-406.

Kurcz I., “Kompetencja językowa i kompetencja komunikacyjna: ich uwarunkowania biologiczne i społeczne. Model wiedzy językowej człowieka", [in:] Język jako przedmiot badań psychologicznych. Psycholingwistyka ogólna i neurolingwistyka, Kurcz I., Okuniewska H. (ed.), Wydawnictwo SWPS, Warsaw, 2011, pp. 35-44.

Łuczyński E., Kategoria przypadka w ontogenezie języka polskiego, czyli o wchodzeniu dziecka w rzeczywistość gramatyczna, Wydawnictwo UG, Gdańsk, 2004.

Malendowicz J., O poprawność pisemnych wypowiedzi uczniów klas I-IV, WSiP, Warsaw, 1974.

Małkowska-Zegadło H., Rozwój języka mówionego i pisanego uczniów w wieku 8-11 lat, Wydawnictwa Szkolne i Pedagogiczne, Warsaw, 1983.

Markowski A., Nowy słownik poprawnej polszczyzny, PWN, Warsaw, 1999.

Markowski A., Kultura jezzyka polskiego. Teoria. Zagadnienie leksykalne, PWN, Warsaw 2005.

Michalik M., Diagnozowanie kompetencji lingwistycznej ucznia szkoły specjalnej, Wydawnictwo Naukowe AP, Cracow, 2006.

Michalik M., Kompetencja składniowa w normie $i$ w zaburzeniach, Wydawnictwo Naukowe UP, Cracow, 2011.

Mnich M., Sprawność językowa dzieci w wielu wczesnoszkolnym, Oficyna Wydawnicza "Impuls", Cracow, 2002.

Nowak F., “Błędy fleksyjne i słowotwórcze w pracach pisemnych uczniów szkół podstawowych", Język Polski w Szkole: dla klas IV-VIII, vol. 4, 1990/1991, pp. 97-106.

Nowak F., “Błędy językowe w zakresie kompozycji zdania złożonego”, Język Polski w Szkole: dla klas IV-VIII, vol. 2/3, 1990/1991, pp. 74-77. 
Piekarska J., Błędy językowe uczniów z inteligencją niższa niż przeciętna, Difin, Warsaw, 2015.

Polański E., "Błędy leksykalne uczniów klas IV-VIII. Part 1", Jezzyk Polsk i w Szkole: dla klas IV-VIII, vol. 2, 1981/1982, pp. 75-80.

Polański E., "Błędy leksykalne uczniów klas IV-VIII. Part 2", Jezyk Polsk i w Szkole: dla klas IV-VIII, vol. 4, 1981/1982, pp. 65-82.

Polański E., Przybyła Olga, “Odstępstwa od normy językowej u uczniów w zintegrowanym kształceniu wczesnoszkolnym", Nauczyciel i Szkota, no. 3/4, 2002, pp. 185-195.

Porayski-Pomsta J., "Kultura języka", [in:] Nauka o jezzku dla polonistów, S. Dubisz (ed.), Wydawnictwo Książka i Wiedza, Warsaw, 1996, pp. 57-100.

Porayski-Pomsta J., "O tzw. błędach językowych dzieci”, Wychowanie w Przedszkolu, vol. 8, 2002, p. 1.

Rakowska A., Język, komunikacja, niepetnosprawność. Wybrane zagadnienia, Wydawnictwo Naukowe AP, Cracow, 2003.

Saloni Z., Błędy językowe w pracach pisemnych uczniów liceum ogólnokształcacego. Próba analizy jezykoznawczej, Państwowe Zakłady Wydawnictw Szkolnych, Warsaw, 1971.

Smoczyńska M., "Metodologiczne problemy analizy błędów językowych dzieci", [in:] Wiedza a jezzyk, vol. 2. Jezyk dziecka, Kurcz I., Shugar G.W., Bokus B. (ed.), PAN, Wrocław-Warsaw-Cracow-Gdańsk-Łódź, 1987, pp. 95-116.

Stawinoga R., Twórczość językowa dziecka w teorii i praktyce edukacyjnej, Wydawnictwo Uniwersytetu Marii Curie-Skłodowskiej, Lublin, 2007.

Tarkowski Z., "Agramatyzm u uczniów lekko upośledzonych umysłowo", [in:] Rewalidacja dzieci ze złożonymi upośledzeniami, Sękowska Z. (ed.), Wydawnictwo UMCS, Lublin, 1988, pp. 81-108.

Tarkowski Z., "Zaburzenia mowy dzieci upośledzonych umysłowo", [in:] Logopedia - pytania i odpowiedzi. Podręcznik akademicki, vol. 2. Zaburzenia komunikacji językowej u dzieci i osób dorostych, Gałkowski T., Jastrzębowska G. (eds.), second edition extended and amended, Wydawnictwo UO, Opole, 2003, pp. 203-209.

Tarkowski Z., "Mowa osób upośledzonych umysłowo i jej zaburzenia", [in:] Podstawy neurologopedii, T. Gałkowski, E. Szeląg, G. Jastrzębwska (eds.), Wydawnictwo UO, Opole, 2005, pp. 553-606.

Wątorek A., Kompetencja językowa uczniów z lekka niepetnosprawnościa intelektualna, Wydawnictwo Nomos, Cracow, 2014.

Wińska U., Błędy językowo-stylistyczne uczniów szkót podstawowych województwa gdańskiego, part I-II, WSP, Gdańsk, 1966.

Żytko M., Pozwólmy dzieciom mówić i pisać - w kontekście badań umiejętności językowych trzecioklasistów, Central Examination Commission, Warsaw, 2010. 